\title{
Így járunk mi - egészséges önkéntesek klinikai járásanalízise
}

\author{
DR. TEREBESSY TAMÁS, DR. SZIJÁRTÓ ANNAMÁRIA, \\ DR. GRESITS ORSOLYA, KRAUSZ KORNÉLIA, DR. KISS SÁNDOR, \\ DR. SZÖKE GYÖRGY
}

\section{ÖSSZEFOGLALÁS}

A Semmelweis Egyetem Ortopédiai Klinikán 2011-ben jött létre háromdimenziós mozgásanalízisre alkalmas járáslabor. A klinikai járáselemzés során a vizsgált egyén mozgásának kinetikai és kinematikai jellemzőit leíró görbéket egészséges egyének jellemzőihez hasonlítják. A standard görbéket minden járásanalitikai laborban egyénileg kell kialakítani. A mérés célja a laborra és a populációra jellemző standard görbék felvétele volt. A szerzők 29 egészséges önkéntes háromdimenziós járásanalízis-vizsgálatát végezték el. A mérésekhez a Vicon cég Plug-in-Gait modelljét használták, amely az alsó végtagot négy szegmentumra (medence, comb, lábszár és láb) osztja. Az eredmények kinematikai elemzése során a négy szegmentum ízületeinek háromdimenziós mozgása kerül ábrázolásra. Kinetikai elemzés a padlóba épített nyomásmérő lap adataiból számolja ki a szegmentumokat összekötő ízületekre ható forgatónyomatékot. A vizsgált 29 egészséges személy járásgörbéinek összegzéséből alakították ki a járáslabor standard görbéit. A kapott adatokat két további járásanalízis labor standard görbéivel is összevetették. Tíz görbe esetén a három labor eredményei egyeznek, míg két esetben, a térd ab/addukciós és a térd rotációs görbéken, eltérés tapasztalható. A járásanalízis labor további vizsgálatainak értékeléséhez a jelen méréssorozat eredményei adják a standard görbéket. A standard görbétől való eltérés számszerűsítésére a laborban bevezették a Gait Deviation Index használatát.

\section{Kulcsszavak: $\quad$ Alsó végtag; Biomechanika; Háromdimenziós mozgásanalízis; Járásanalizis; Ízületi mozgásterjedelem; Kinematika;}

T. Terebessy, A. Szijártó, O. Gresits, K. Krausz, S. Kiss, Gy. Szőke: The way we walk - Clinical gait analysis of healthy volunteers

In 2011 a three-dimensional gait analysis lab was established at Semmelweis University Department of Orthopaedics. During a clinical gait analysis kinematic and kinetic curves describing a patient's motion features are compared to standard graphs. These standard gait graphs have to be established individually in each gait analysis lab. The purpose of this study was to create the standard graphs what refer to our population and lab. Three-dimensional gait analysis was performed on 29 healthy volunteers by using VICON's Plug-in-Gait model. This model divides the lower extremity into 4 segments (pelvis, thigh, shank, foot). Kinematic evaluation shows the three-dimensional motion of the joints connecting these segments. Kinetic evaluation calculates the torque in joints connecting the segments, using data from a force plate mounted in the floor. We summarized the gait graphs of the 29 healthy volunteers to create our gait lab's standard gait curves. We also compared our data with standard graphs of two other gait analysis laboratories. 10 curves matched, but 2 curves (knee ab/adduction and knee rotation) appeared different. For evaluating further clinical gait measurements in our lab, we are going to use our standard graphs established as a result of this study. To quantify deviation from standard curves use of Gait Deviation Index was commenced.

\section{Key words:}

Biomechanical Phenomena; Gait - Physiology; Imaging, three-dimensional - Instrumentation; Joints - Physiology; Leg; - Physiology; Walking - Physiology; 


\section{BEVEZETÉS}

A háromdimenziós (3D) járásanalízis Kadaba, Gage és Perry munkája nyomán tekinthető standard eljárásnak. Kadaba és Gage a „,konvencionális járásmodellt”, azaz a statisztikai biztonsággal ismételhető adatgyűjtési, feldolgozási és értékelési technikát fejlesztette ki, Perry pedig a járás biomechanikáját vizsgálva dolgozta ki a járásciklus máig használatos felosztását $(3,6,9)$. A 3D járásanalízis technikai és informatikai fejlődése lehetővé tette, hogy az eljárás napi rutinná váljon a mozgásszervi gyógyászat számos területén. Az elmúlt 20 évben az infantilis cerebralis paresisben és egyéb spasticus állapotokban a klinikai járásanalízis jelentős szerepet kapott a járászavarra vezető perifériás musculoskeletalis okok diagnosztikájának pontosításában, valamint a járáskép javítását célzó beavatkozások tervezésében $(4,8)$. Több járáslaborban végeznek rutin méréseket alsóvégtagi fejlődési rendellenességben szenvedők mútéti és orthetikai korrekciójának megítéléséhez, de a múvégtagok mind tökéletesebb biomechanikájának kialakításánál is gyakorta alkalmazott eljárás $(1,2,10)$.

A klinikai járásanalízis során a mért eredmények, azaz a páciens járásának (mozgásának) háromdimenziós kinematikai és kinetikai jellemzőit leíró mozgásgörbék egészséges önkéntesek járásjellemzőihez hasonlíthatók. Az önkéntesek „járásgörbéinek átlagából” számított, standard görbéket minden járásanalízis laborban egyénileg kell kialakítani, így alkalmazkodva ahhoz, hogy a standard görbék a technikai környezet, a mérést végzők személye és a populáció járásmintázatának különbözősége miatt járáslaboronként kissé eltérőek lehetnek.

A Semmelweis Egyetem Ortopédiai Klinikáján 2011-ben létesült 3D járásanalízis labor. A tesztüzem ideje alatt külföldi járáslaborok referenciagörbéit használtuk. 2013. december óta a laborunkban kidolgozott standard járásgörbéket használjuk.

\section{MÓDSZEREK}

\section{Egészséges önkéntesek}

A Semmelweis Egyetem Ortopédiai Klinika járáslaboratóriumában 2012. január és 2013. december között 29 egészséges önkéntes 3D járásvizsgálatát végeztük. Az önkéntesek átlagéletkora 21,5 $\pm 7,1$ év (17 nö, 12 ffi), testtömege $62,3 \pm 18,6 \mathrm{~kg}$, testmagassága $167,2 \pm 16,1$, BMI értéke $21,8 \pm 3,8$ volt. Az önkénteseknek nem volt ortopédiai deformitása vagy betegsége.

\section{Plug-in-Gait modell}

Hat infrakamerás (Vicon MX T40) 3D járásanalízis rendszert használtunk a kinematikai adatok rögzítéséhez, amelyet egy padlóba épített erőmérő lap (AMTI OR 6-7) használatával egészítettünk ki a kinetikai adatgyújtéshez. A mért adatokat Vicon Nexus 1.8 .2 szoftver segítségével dolgoztuk fel. A 3D mozgásanalízishez Vicon Plug-In-Gait modellt használtunk (12). A mérés során Plug-In-Gait marker protokollnak megfelelően, az alsó végtagok meghatározott anatómiai pontjaira reflektív markerek kerülnek, amelyek térbeli koordinátáit a járásanalízis rendszer folyamatosan rögzíti. A Plug-In-Gait marker protokoll szerint marker kerül jobb és bal oldalon szimmetrikusan az elülső és hátsó csípőtövisekre, a térdek laterális epicondylusaira, a külbokákra, a térdmarkert a nagytomporral összekötő egyenes alsó harmadoló pontjára, a boka és a térdmarkert összekötő egyenes alsó harmadoló pontjára, a második metatarsus fejre és a sarokcsont gumójára a metatarsus fejet jelölő marker magasságában (1. ábra). A markerek pozíciójának ismeretében a rendszer az alsó végtag mozgásait a medence, a combok, a lábszárak és a lábak, mint egymáshoz gömbcsuklóval kapcsolódó merev testek mozgásaként írja le. Eredményeinket Vicon Polygon 3.5.1 szoftver segítségével jelenítjük meg.

A kinematikai elemzés során az alsó végtag fent leírt szegmentjei közti ízületek 3 síkú mozgása kerül ábrázolásra. A medence szagittális síkú billenése, frontális síkú ferdesége és horizontális síkú rotációja a járáslabor saját koordináta rendszeréhez viszonyítva látható. $A$ comb flexiós/extenziós, ab/addukciós és rotációs mozgásai a medencéhez képest vannak ábrázolva. A csípőízületben a forgástengelyeket a két csípő mozgásközéppontját összekötő egyenes, a csípőközéppontból állított, az előbbire merőleges (szagittális) irányú egyenes, és a comb hossztengelye adják. A lábszár flexiós/ 
extenziós, valgus/varus irányú, valamint rotációs mozgásai a combhoz, a láb mozgásai a lábszárhoz viszonyítva láthatók. A boka forgástengelyeit a bimalleolaris tengely, a boka forgásközpontjában erre merőleges (szagittális) irányú tengely és a lábszár hossztengelye képzik (2. ábra). A kinetikai értékeléskor az alsó végtagi szegmentumok közötti ízületekben ébredő forgatónyomatékok kerülnek ábrázolásra. A Vicon Polygon 3.5.1 szoftverben a mért adatok egy járásciklusra normalizálva, idő helyett százalék függvényében kerülnek megjelenítésre. Egy járásciklus alatt 100 mérési pontot jelenít meg a program. Ilyen módon válik lehetővé a különböző járássebességű egyének járásának összehasonlítása.
A Plug-in-Gait modell grafikonokon szürke sáv jelzi az egészséges önkéntesek „standard” mozgásgörbéit, a sáv szélessége a szórás nagyságát mutatja. A betegvizsgálati grafikonokon feltüntetésre kerül a standard szürke sáv, valamint a páciensek mért járásgörbéi jobb (zöld) és bal (piros) járásciklusként külön-külön ábrázolva. Általánosan elfogadott, hogy a páciensek járásképét a többszörös mérés ellenére nem átlagolva, hanem a járásképre legjellemzőbb görbével jelenítjük meg. Ha a vizsgált páciens járásgörbéje a szürke sávon kívül van, akkor pontosan megítélhető, hogy a járásciklus mely fázisában milyen mértékben tér el a normál mintázattól (3. ábra).
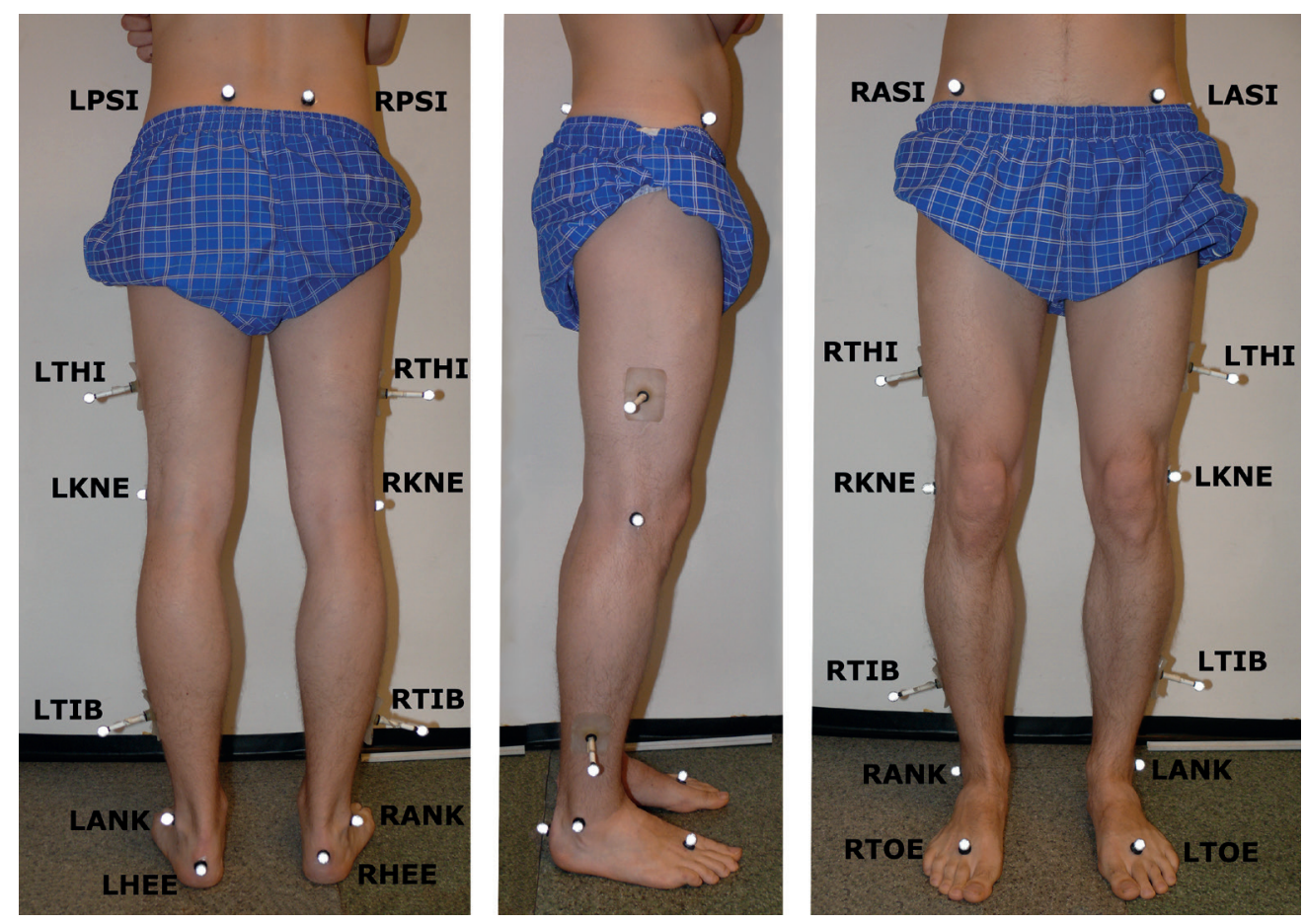

1. ábra A VICON cég Plug-in-Gait modell markerprotokollja

A mozgásanalízissel kapcsolatos szakirodalomban a markerek anatómiai pozíciójának angol nyelvü rövidítése terjedt el. A VICON Nexus szoftver a markerek megnevezésére automatikusan az angol nyelvü röviditéseket használja. Marker került a négy csípötövisre (LASI, RASI, LPSI, RPSI), a térdek lateralis epicondylusaira (LKNE, RKNE), a külbokákra (LANK, RANK), a térdmarkert a nagytomporral összekötö egyenes alsó harmadoló pontjára (LTHI, RTHI), a boka és a térdmarkert összekötö egyenes alsó harmadoló pontjára (LTIB, RTIB), a második metatarsus fejre (LTOE, RTOE) és a sarokcsont gumójára a metatarsus fejet jelölö marker magasságában (LHEE, RHEE). 


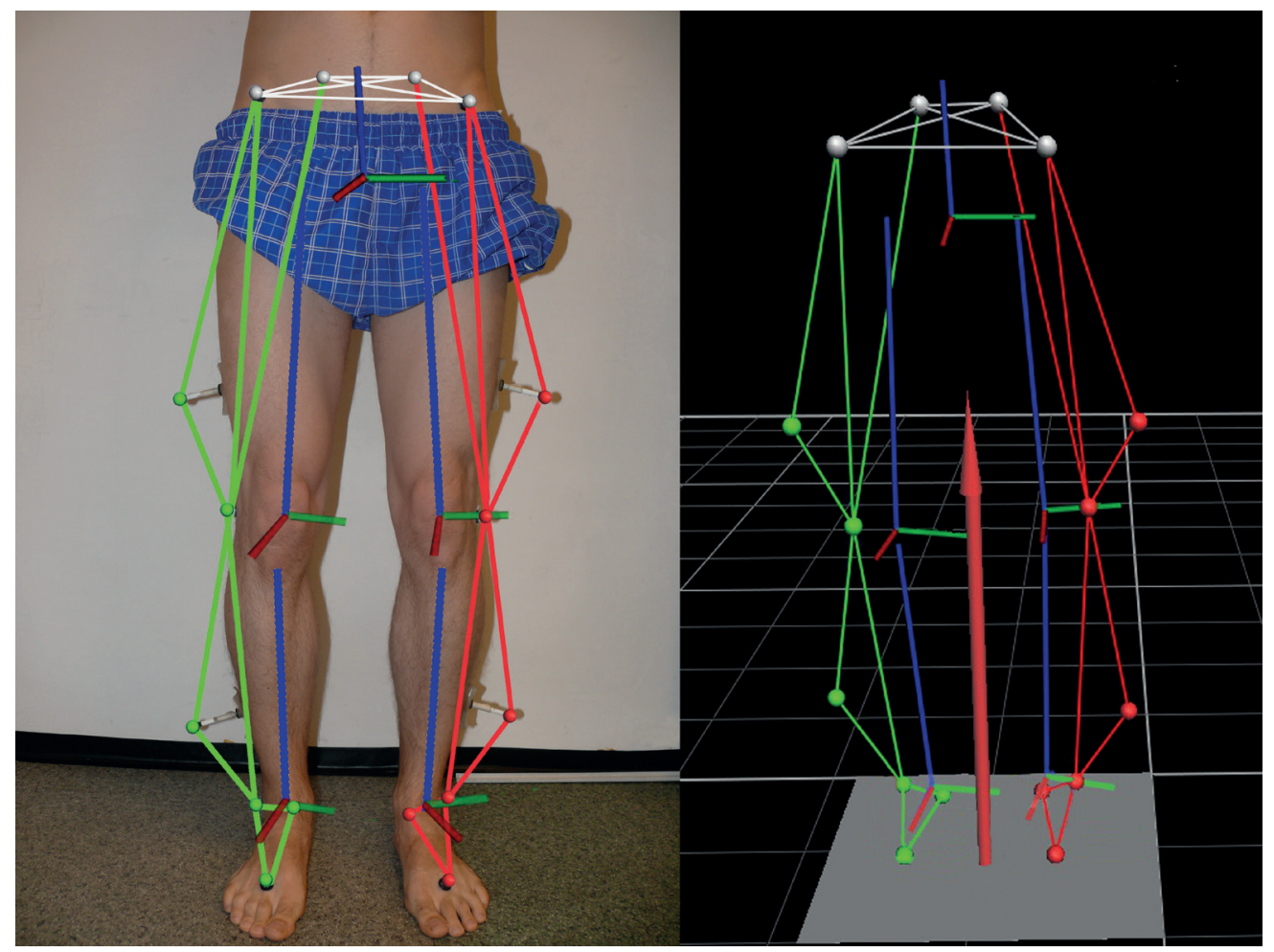

2. ábra $A 3 D$ járásanalizis Plug-in-Gait modellje

Az ábra bal oldalán egyik önkéntesünk fényképére vetített Plug-in-Gait modell sematikus rajza, jobb oldalán a szoftver által leképezett 3D kép látható. A program a modellezett ízületi mozgások tengelyeit (a medenceszegment, a térdízület és a bokaízület tengelyeit) jeleníti meg. A vizsgált egyén az erőmérő lapon áll, a jobb oldali vastag, piros nyíl az erővektort mutatja.
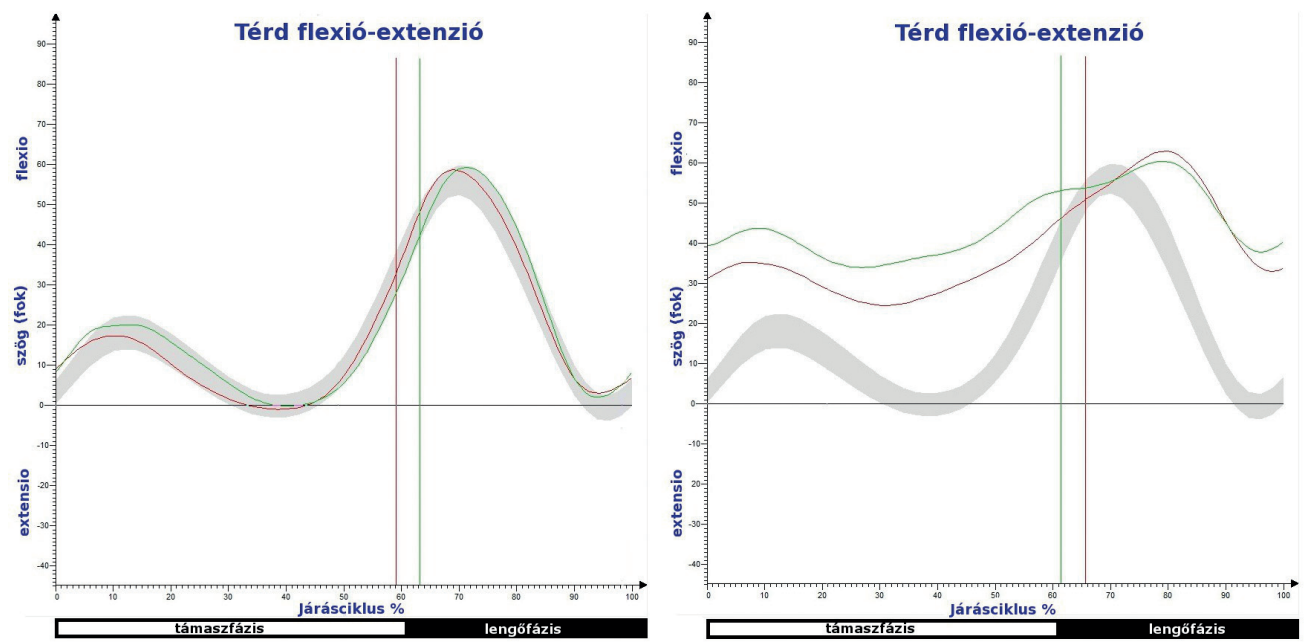

3. ábra Egészséges és ICP-s beteg térdflexiós görbéi

Szemléltetésként egy egészséges (bal oldal) és egy spasztikus (jobb oldal) betegünk térd flexiós görbéi láthatók egymás mellett. A spasztikus beteg térde a támaszfázis során végig flexióban van. A görbéken egy járásciklus látható. A jobb láb zölddel, a bal pirossal ábrázolódik, a függöleges vonal a láb elrugaszkodásának pillanatát jelöli. A szürke sáv a cikkben szereplö 29 egészséges önkéntes járásgörbéinek összessége. 


\section{JÁRÁSINDEX}

A standard járásgörbék kiváló összehasonlítási alapot nyújtanak a betegek járása során észlelhető eltérések részleteinek észleléséhez és elemzéséhez. Az elemzés azonban nehézkes, lassú, továbbá némi hozzáértést és gyakorlatot igényel. A fenti problémák kiküszöbölésére alkották meg a járásindexeket, amelyek közül a legismertebbek a Gillette Gait Index (GGI) és a Gait Deviation Index (GDI). Laborunkban első lépésben, a Gillette Gait Indexnél egyszerúbb járásindex, a Gait Deviation Index, bevezetése mellett döntöttünk $(5,11)$. A GDI-t járáseltérési indexnek fordítottuk, rövidítésére azonban továbbra is a GDI-t használjuk.

A GDI a járás jellemzésére 9, a konvencionális járásmodell (Plug-In-Gait) alkalmazásából származó görbe normálistól való eltérését használja. A 9 görbe a medence szagittális billenése, frontális ferdesége és rotációja, valamint a csípőízület flexiós/extenziós, ab/addukciós és rotációs mozgásai, továbbá a térdízület flexiós/extenziós és a boka dorzál/plantár flexiós mozgása és a lábtengely haladási iránynyal bezárt szöge (foot progression angle) a járásciklus során. A páciensek járásgörbéinek a standardtől való eltérései százalékos formában kerülnek kiszámításra. A kapott eredményben minden 10 pont változás egy szórásnyi (1×SD) eltérést jelent a normál járásképtől.

\section{EREDMÉNYEK}

A háromdimenziós infrakamerás rendszerű járásanalízis nem jelent újdonságot a járásképet jellemző időjellegű (lépésidő, ciklusidő, támaszfázis-időtartam, lendítőfázisidőtartam, kettős támaszfázis-időtartam) és távolságjellegű (lépéshossz, lépésciklushossz, lépésszélesség) változók meghatározásában, ezért ezen paraméterek értékelését jelen közleményünkben nem tárgyaljuk. Adatfeldolgozás után az alsó végtagi Plug-in-Gait modell a medence, a csípő, a térd és a boka háromdimenziós szögelfordulás (kinematika) és ugyanezen szegmentumok forgatónyomaték (kinetika) görbéit adja eredményül. A 29 egészséges önkéntes járásvizsgálatának eredményeiből kialakított standard görbéket a 4. és 5. ábra tartalmazza. Hitelesítés céljából a kialakított standard görbéinket két külföldi járáslabor („Gait lab 1" és "Gait lab 2") rutinszerűen használt referencia-járásgörbéivel hasonlítottuk össze (6. ábra). A külföldi laboratóriumok mérési sorozatának eredményei nem álltak rendelkezésre, ezért statisztikai összehasonlítást nem tudtunk végezni, csak a saját méréseinktől való eltérést tudtuk a járásciklus minden egyes pillanatában meghatározni. A görbék elemzésénél megállapítható, hogy a külföldi járáslaborok standard görbéi két esetben, a térd frontális síkú és rotációs görbéin térnek el a saját adataink átlag士szórás értékeitől (7-8. ábrák). A térd ab/addukciós görbén a járás támaszfázisának végén és a kezdeti lengő fázisban "Gait lab 1" adataival megegyezo módon enyhe varus irányú térdpozíciót regisztráltunk $(5,24 \pm 1,37$ és $7,46 \pm 1,19$ fok), „Gait lab 2" adatai ezzel szemben neutrális helyzetű térdet jeleznek $(0,66 \pm 1,70$ fok). A térd rotációs görbén a járás lengő fázisában saját adataink "Gait lab 2" adatainak megfelelően enyhe berotációt mutatnak $(4,33 \pm 2,02$ és $3,79 \pm 3,05$ fok), míg "Gait lab 1" a járás ugyanezen fázisában enyhe kirotációt igazolt $(-4,88 \pm 2,63$ fok). Egyéb kinematikai és kinetikai görbéken nem észleltünk a saját méréseink átlag₫szórás értékeinél nagyobb eltérést. A kinematikai járásgörbékből származó eremények alkalmas matematikai adatbázist nyújtanak a továbbiakban vizsgált betegek járáseltérési indexének (GDI) számításához. 

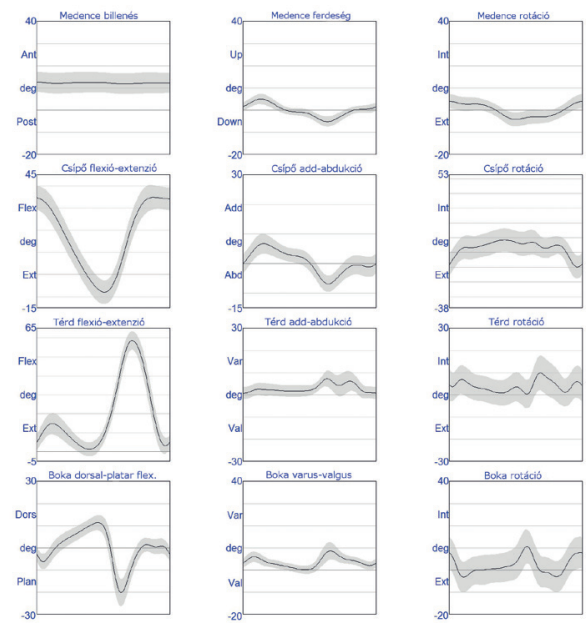

4. ábra A vizsgált egyének kinematikai görbéinek összessége

Önkénteseink járására leginkább jellemző kinematikai görbéket egy ábrán tüntettük fel, majd a vonalak sokaságára burkoló görbét illesztettünk. Az így kapott szürke sáv szélessége a szórást jelöli. A vastag, középső vonal az átlagot ábrázolja.
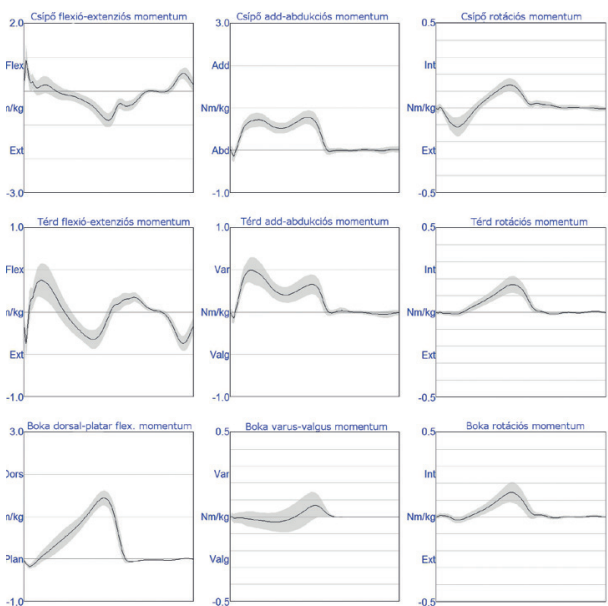

5. ábra A vizsgált egyének kinetikai görbéinek összessége

Az önkéntesek járásanalizisének eredményéből alkotott kinetikai standard görbéink. A padlóba süllyesztett nyomásmérő eszköz adatai, a vizsgált alany mérhető paraméterei (például súly, magasság, lábhossz) és a felhelyezett markerek mozgása alapján a szoftver kiszámítja az egyes izületekre ható, pillanatnyi forgatónyomatékokat. A görbéken a vektor nagysága látható a járásciklus során, a szövegben részletezett izületi forgástengelyek tükrében.
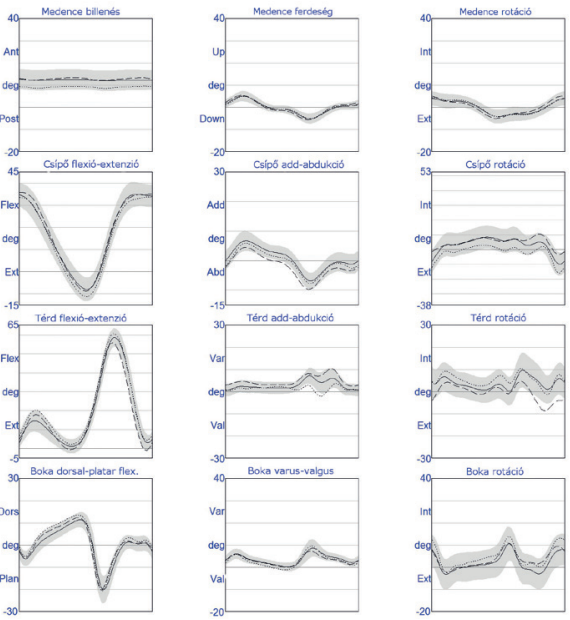

6. ábra Saját laborunk és két másik 3D járásanalizislabor standard görbéi

A saját adataink átlagát folyamatos, a másik két laborét pöttyözött és szaggatott vonalak jelzik. Az összehasonlításhoz használt két másik labor Leuvenben (UZ Leuven

Laboratorium voor klinische bewegingsanalyse) és Oxfordban (Oxford Gait Laboratory) müködik. 


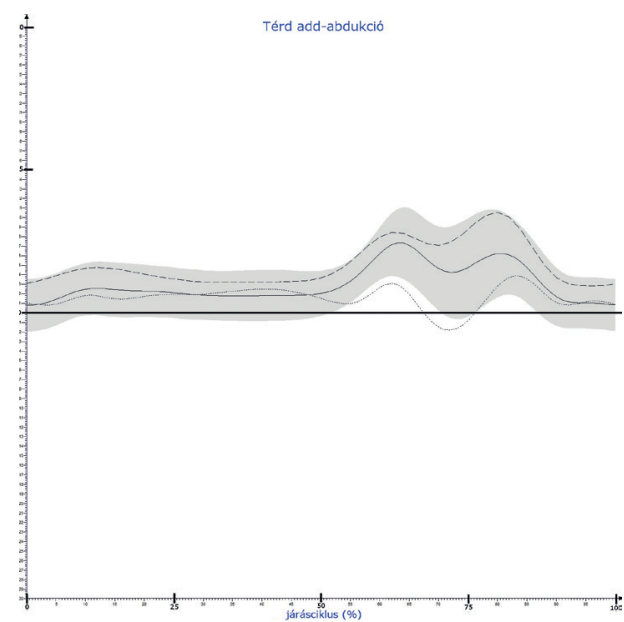

7. ábra A három labor térd add/abdukciós görbéi A saját adataink átlagát folyamatos, „Gait Lab 1" adatainak átlagát szaggatott, "Gait Lab 2" adatainak átlagát pöttyözött vonal jelzi. A három labor standard görbéi a lengő fázisban eltérnek egymástól. Saját adataink a járás támasz fázisának végén és a kezdeti lengő fázisban - „Gait Lab 1" adataihoz hasonlóan - enyhe varus irányú térdpozíciót mutat, "Gait Lab 2" adatai ezzel szemben neutrális helyzetű térdet jeleznek. A térdmarker helyzete valamenynyi marker közül a leginkább vizsgáló-függö, mely tény magyarázhatja az eltérést.

\section{MEGBESZÉLÉS}

$\mathrm{Az}$ alsó végtagi háromdimenziós járásanalízis megbízható és ismételhető módon ad képet a járásmintázatról. Megítélhető a nagyízületek járás közbeni helyzete, és az ízületi helyzetek jól összehasonlíthatók a standard járáskép ízületi helyzeteivel. Jelen tanulmányunkban járáslaboratóriumunk saját standard adatbázisának kidolgozását mutattuk be. Standard adatainkból készült, az alsó végtagi ízületek mozgását leíró kinematikai, valamint az ízületekre ható forgatónyomatékokat bemutató kinetikai görbéket két külföldi járáslabor görbéivel hasonlítottuk össze. Az összehasonlítás során eltérést észleltünk a térd ab/addukciós görbén a járás lengőfázisában (7. ábra), azonban ezen a ponton a két külföldi labor referenciagörbéi is jelentősen eltérnek egymástól. A térd ab/addukciós helyzetének kalkulálása érzékenyen függ a lateralis femur epicondylusra helyezett (LKNE/RKNE) marker helyzetétől. A marker pontos pozicionálása az egyik legnehezebb feladat a 3D járásanalízis során. Saját adataink a térd ab/addukciós

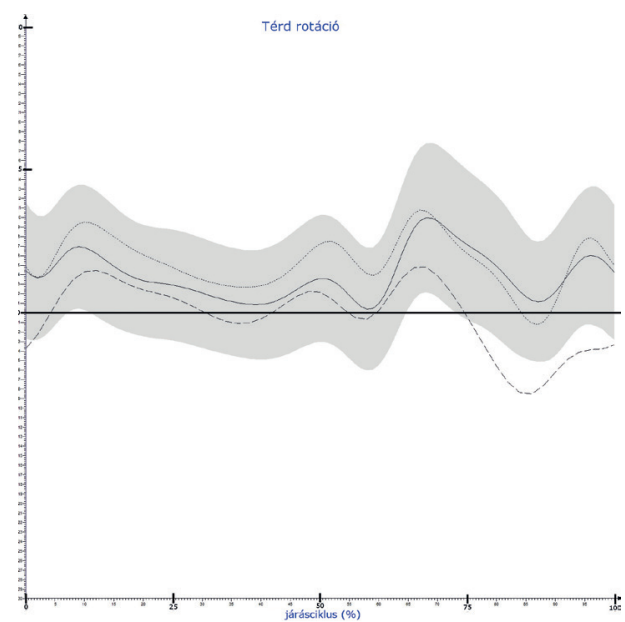

8. ábra A három járáslabor térd rotációs görbéi A saját adataink átlagát folyamatos, "Gait Lab 1" adatainak átlagát szaggatott, "Gait Lab 2" adatainak átlagát pöttyözött vonal jelzi. A saját átlagunk érdemi eltérést nem mutat "Gait Lab 2" labor átlagától. Eltérés észlelhető viszont a lengő fázisban „Gait Lab 1" átlagától. Az eltérés okát itt is a térdmarker felhelyezésének nehézsége magyarázhatja.

görbe esetében a két külföldi referenciagörbe között helyezkedik el, így a különbségeket vélhetően a három labor eltérő térd marker felhelyezési rutinja okozza.

Szintén eltérést találtunk a térd rotációs görbén ugyancsak a járás lengő fázisában (8. ábra). Ebben az esetben saját mérési eredményeink az egyik referenciagörbével teljesen megegyező értékeket mutatott, míg a másik külföldi labor eredményei ettől eltérőek voltak. A fenti két esetben a pontosabb referenciagörbék nem voltak elérhetők ezért a saját méréseink adatait tekintjük standard adatbázisnak minden további kinematikai és kinetikai vizsgálat esetén.

A standard adatbázis fejlesztéssel párhuzamosan kidolgoztuk és bevezettük a járáseltérési index (GDI) használatát. A járásindexek alkalmazásával a járásmintázatban észlelhető eltérések részletei ugyan elvesznek, de a teljes járáskép normálistól való eltérése egyetlen számmal jellemezhető, ami könnyen értelmezhető és gyors értékelést tesz lehetővé a betegek járásképének egészségesekkel történő, 
vagy a beavatkozás előtti és utáni állapot, esetleg jobb és bal oldali lépésmintázat összehasonlítására (7).

A kinematikai, és kinetikai vizsgálatokhoz kidolgozott standard adatbázis és görbék, valamint a GDI bevezetése kapcsán a Semmelweis Egyetem Ortopédiai Klinika járáslaboratóriumában teljes klinikai és kísérletes 3D járásvizsgálatok végezhetők a magyarországi, egészséges mozgásszervrendszerű populáció standard adataihoz hasonlítva. A későbbiekben járáslaborunkban további standard adatbázisok kidolgozását tervezzük a járás közben az alsó végtag izmairól elvezethető EMG mérésekhez, valamint a lépés során pedobarogáffal mérhető talpi nyomáseloszlás meghatározáshoz.

\section{Köszönetnyilvánítás}

A járáslaboratórium a Gerincőr TECH-08-A 1/2-2008-0121 számú kutatási projekt anyagi támogatásával valósult meg.

\section{IRODALOM}

1. Ackman J., Altiok H., Flanagan A., Peer M., Graf A., Krzak J., Hassani S., Eastwood D., Harris G.F.: Long-term follow-up of Van Nes rotationplasty in patients with congenital proximal focal femoral deficiency. Bone Joint J. 2013. 95-B. (2): $192-198$. http://dx.doi.orq/10.1302/0301-620X.95B2.30853

2. Aiona M., Do K. P., Emara K., Dorociak R., Pierce R.: Gait patterns in children with limb length discrepancy. J. Pediatr. Orthop. 2015. 35. (3): 280-284.

3. Davis III R. B., Ounpuu S., Tyburski D., Gage J. R.: Gait analysis data collection and reduction tecnique. Human Movement Science. 1991. 10. (5): 575-587. http://dx.doi.org/10.1016/0167-9457/91)90046-Z

4. Gage J. R.: Gait analysis. An essential tool in the treatment of cerebral palsy. Clin. Orthop. Relat. Res. 1993. 288. (3): 126-134.

5. Haumont T., Church C., Hager S., Cornes M.J., Poljak D., Lennon N., Henley J., Taylor D., Niiler T., Miller F.: Flexedknee gait in children with cerebral palsy: a 10-year follow-up study. J. Child. Orthop. 2013.7. (5): $435-443$. http://dx.doi.org/10.1007/s11832-013-0505-8

6. Kadaba M. P., Ramakrishnan H. K., Wootten M. E., Gainey J., Gorton G., Cochran G. V.: Repeatability of kinematic, kinetic, and electromyographic data in normal adult gait. J. Orthop. Res. 1989. 7. (6): 849-860. http://dx.doi.org/10.1002/jor.1100070611

7. McMulkin M. L., MacWilliams B. A.: Application of the Gillette Gait Index, Gait Deviation Index and Gait Profile Score to multiple clinical pediatric populations. Gait Posture. 2015. 41 (2): 608-612. http://dx.doi.org/10.1016/i.gaitpost.2015.01.005

8. Narayanan U. G.: The role of gait analysis in the orthopaedic management of ambulatory cerebral palsy. Curr. Opin. Pediatr. 2007. 19. (1): 38-43. http://dx.doi.org/10.1097/MOP.0b013e3280118a6d

9. Perry J.: Gait analysis: Normal and pathological function. Thorofare, New Jersey. SLACK Incorporated. 1992.

10. Rietman J. S., Postema K., Geertzen J. H.: Gait analysis in prosthetics: opinions, ideas and conclusions. Prosthet. Orthot. Int. 2002. 26. (1): 50-57. http://dx.doi.org/10.1080/03093640208726621

11. Schwartz M. H., Rozumalski A.: The gait deviation index: a new comprehensive index of gait pathology. Gait Posture, 2008. 28 (3): 351-357. http://dx.doi.orq/10.1016/i.qaitpost.2008.05.001

12. Vicon ${ }^{\circledR}$ Plug-in-Gait modelling instructions Vicon ${ }^{\circledR}$ Manual, Vicon ${ }^{\circledR} 612$ Motion Systems, Oxford Metrics Ltd., Oxford, UK. 2002.

\section{Dr. Terebessy Tamás}

Semmelweis Egyetem Ortopédiai Klinika

1082 Budapest, Üllői út 78/b

terebessy.tamas@med.semmelweis-univ.hu 